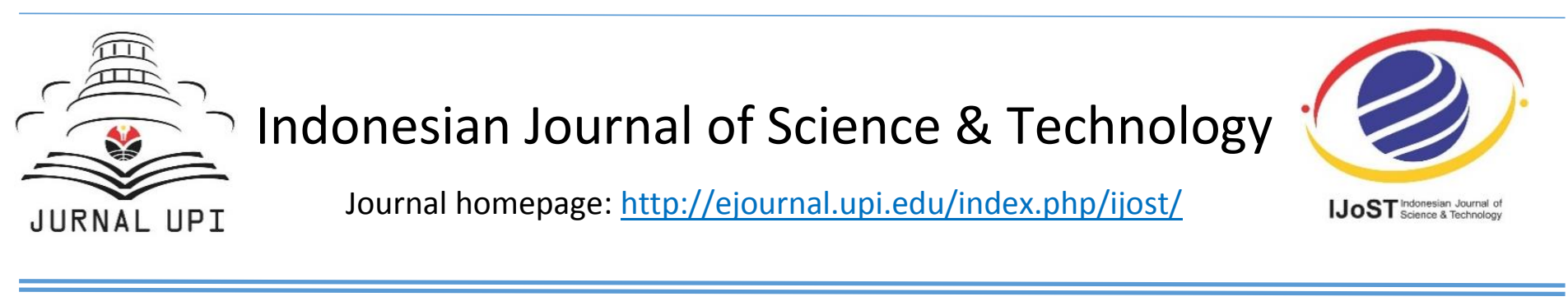

\title{
Utilization and Quality of Information System for Administration Services Based on ICT In Patehan, Kraton, Yogyakarta
}

\author{
Amandita 'Ainur Rohmah ${ }^{1 \bowtie}$, Rini Rachmawatl' \\ ${ }^{1}$ Department of Geography Development, Faculty of Geography, Universitas Gadjah Mada, Indonesia \\ ${ }^{\square}$ Correspondence: E-mail: amandita.ugm@gmail.com
}

\begin{abstract}
A B S T R A C T
Development of technology and application of e-government at city, sub-district, and village become the factor of emergence of Information and Communication Technologybased information service system innovation. Yogyakarta has implemented e-government as one of the strategies used to achieve the slogan of Yogyakarta Smart City. One of the areas that have implemented the concept is Patehan, Kraton, Yogyakarta. This research aims to describe the system of online administrative services, identify of utilization by the community, and measure the quality of its services. The research methods used were qualitative and quantitative methods. Data collected are primary data and secondary data with analytical techniques used are descriptive qualitative and quantitative. Based on the results of the research, it can be seen that the administrative service system in Patehan (SiWarga Patehan) is a system made by citizens, for citizens, and from citizens to take care of online certificate from RT, RW until the village that serve as one alternative for the community that has high mobility. Based on 60 respondents, it can be concluded that the administrative system of SiWarga Patehan included into the category of good with the service index of 79.97.

(C) 2019 Tim Pengembang Jurnal UPI
\end{abstract}

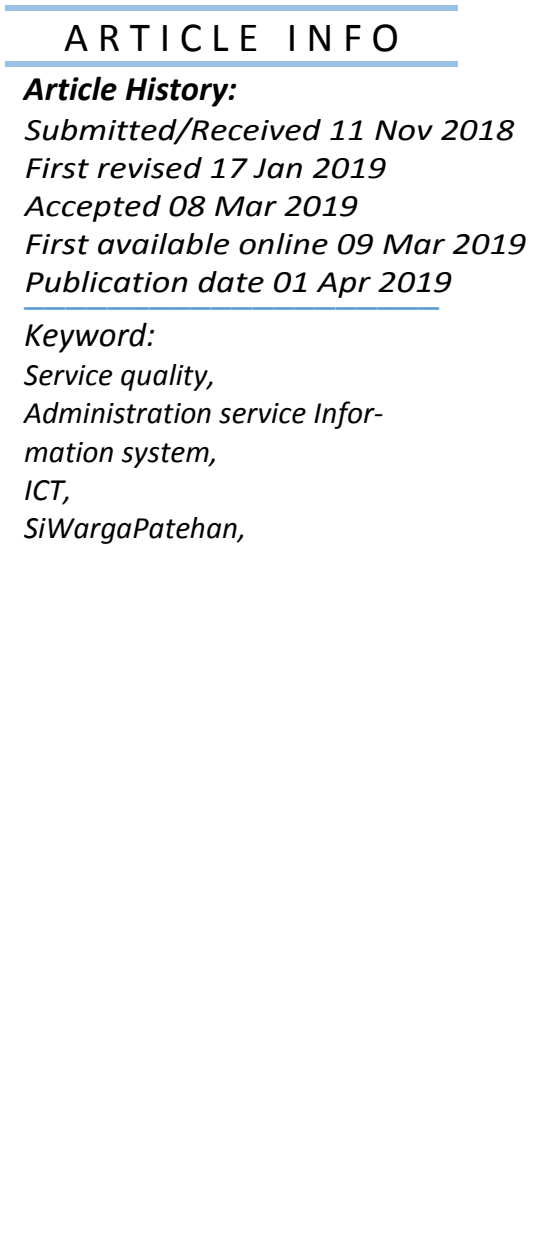

\section{INTRODUCTION}

The low quality of public services in the city, sub-district and even in village level, is one of the most frequent problems in
Indonesia. Village sub-district's administrative service is not doing well because of the imbalance in the number of incoming and outgoing letters with the staff 
resources in the village. With the manual system, village officials will have difficulty in serving the needs of the community in the village which creates various obstacles such as limited service time, long service queues, and a series of administrative procedures at the village level that are deemed inadequate to be the problem of regional service systems in Indonesia. The problem of the service quality can be overcome by improving the quality of human resources and the development of information technology that exists today. The quality of human resources is able to encourage the emergence of new technologies that can help facilitating the administrative system of a region. Furthermore, internet information technology at this time makes all activities can be carried out online, and it will increase the role of virtual space and can eliminate obstacles related to space and time (Rachmawati, 2014).

Digital-based public services are the implementation of the smart city concept that emphasizes the use of ICTs (Rachmawati et al., 2018). Internet is one of the digital media in serving people in an area (Gasova and Stofkova, 2017). The progress of information and communication technology that is increasingly advanced presents various developments in internet applications, one of which is e-government. E-government is the process of using information and communication technology as a tool to help the system of government and public services to be more effective and efficient (Sosiawan, 2008). According to UNDESA (2016), e-government can be one indicator of development because of its role in delivering basic services to the community.

E-government presents in Indonesia as an answer to improving the performance of government agencies and the needs of the community in public services. With the existence of e-government, the government agencies will be helped in delivering information to the public, making it easier to interact with the community, and in time will be more efficient and effective in its services. Viewed from the community side, they will find it easier to access information and services available in government agencies in accordance with the needs of their communities.

The development of e-government began to appear after the government policy through Presidential Instruction No. 3 of 2003 concerning National e-government Development Policy and Strategy. In particular, the development of egovernment in the city of Yogyakarta is regulated in DIY Governor Regulation No. 42 of 2006 and Mayor Regulation No. 78 of 2007. The motto of the City of Yogyakarta as Smart City Yogyakarta is contained in the Yogyakarta City Vision contained in the Mayor's Regulation No. 15 of 2015 namely "The realization of e-government as a means of information system management in Yogyakarta City that is reliable in supporting effective, efficient, transparent, accountable and participatory public services so that it becomes Yogyakarta Smart City".

Good overnance includes various kinds of related stakeholders such as government, society and the private sector. Meanwhile, according to Yousaf et al. (2016), good governance is defined as a process and governance structure that regulates political and socio-economic relations based on several characteristics or indicators such as: participation, legal regulation, transparency, responsiveness and accountability (Paramita et al., 2016).

The vision of Yogyakarta city is becoming Yogyakarta Smart City. The vision encourages the implementation of egovernment at the city, sub-district and village level. One area that has implemented information systems for ICT-based administration services is Patehan, Kraton, Yogyakarta. Patehan became one of the

DOI: http://dx.doi.org/10.17509/ijost.v4i1.12680 | p- ISSN 2528-1410 e- ISSN 2527-8045 | 
pioneers of other villages in Yogyakarta City that applied the concept of e-government in the provision of public services. This study aims to describe the information system of ICT-based administration services in Patehan, identify the utilization of administrative service information systems, and measure the quality of administrative service information systems in Patehan. ICT is important to make the processing system easier and faster (Firdaus et al., 2017; Haristiani and Firmansyah, 2016; Haristiani and Aryadi, 2017). The research methods used were qualitative and quantitative methods.

\section{MATERIAL AND METHODS}

This study used combination of quantitative and qualitative methods. Primary data collection includes observation, in-depth interviews, and questionnaires. The secondary data is taken by collecting data from the village regarding the number of SiWarga Patehan users and literature review of some supporting reading material. Data sampling was carried out using purposive sampling method based on predetermined criteria. Questionnaires were distributed to 60 respondents. The chosen espondents were Patehan residents who had or were using SiWarga to find out who used the most and who used the least. Data analysis was used using qualitative descriptive analysis and quantitative descriptions. The questionnaire consists of closed questions and uses a rating scale with an ordinal measurement scale of score 1 - 4 .

\section{RESULTS AND DISCUSSION}

\subsection{Siwarga patehan administrative ser- vices information system}

The breakthrough in the innovation of the administrative service information system in Patehan, Kraton, Yogyakarta was named Citizens Information System (SiWarga). SiWarga is an online service information system as a form of information technology development that can be accessed through a website or smartphone that is used as an alternative tool in facilitating community administration matters that are urgent so that they can get services quickly without constrained distance and time of service process. SiWarga Patehan has started operating since 2017, and it can be accessed through web address: www.siwargapatehan.com.

SiWarga Patehan contains six main menus which are divided into 18 features and grouped into 6 main menus that are home menu, cover letter, information, population, list of officials, and complaints of citizens. The home menu contains the initial display of SiWarga Patehan which contains commands from other menus. Whereas the cover letter is the main menu in the system. The cover letter is a facility for making administrative cover letters needed by each citizen. SiWarga Patehan Information contains information about population data such as the list of heads of families, the list of residents, and citizen statistics per region. The population menu on the SiWarga Patehan Application is complete because it contains data on the population of all Patehan residents from NIK to personal data such as the blood type data of each resident. The menu of official list is a special menu containing the names of subdistrict staff, subvillage administrators, and institution administrators in Patehan Village. The list of officials makes it easier for public to communicate with administrators in Patehan Village. In addition to the other five menus, SiWarga Patehan is also equipped with a menu of citizen complaints. With this menu, every community is free to provide comments and suggestions regarding services and problems in the Patehan Village area.

Unlike the manual letter, the letter output on the SiWarga Patehan no longer uses signatures and stamps but with a QR Code. The QR Code on SiWarga Patehan has 
been incorporated between the name of the head of the villages, ID number, as well as the number and date of the letter. The purpose of establishing SiWarga Patehan is to accelerate and facilitate services so as to create effective and efficient services, facilitate access to information, and organize administration in Patehan.

SiWarga's new innovation provides a change of mechanism, especially in the administrative service process at Patehan as seen in Figure 1. This is consistent with the opinion of Rachmawati (2016) that the collection of technology and its application can be a dynamic utility for changes in innovations made. The offline administrative service process requires residents to meet directly (face to face) by visiting the house of head of village. Meanwhile, SiWarga Patehan's online service process gives more freedom to citizens to be able to take care of services wherever and whenever citizens need services that can be accessed 24 hours nonstop. Changes in the mechanism from offline to online bring some changes, both in terms of mechanism, data, administration, time, cost and environment. One of the future development plans for SiWarga Patehan is the addition of text Gateway features. SiWarga Patehan is an embryo of the online village service system in the city of Yogyakarta, which is the integration of SiWarga Patehan with resident Web Server with the addition of user photos and feature development.

$$
\begin{aligned}
& \text { Citizen } \Longrightarrow \text { Open the SiWarga website } \longrightarrow \text { Enter NIK and Password } \\
& \text { www.siwargapatehan.com }
\end{aligned}
$$

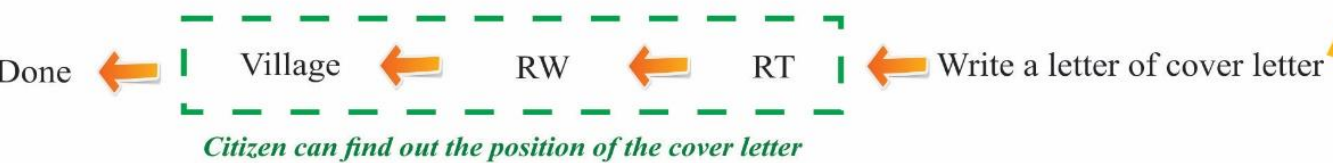

Click the cover letter on the

Figure 1. The Mechanism and Flow of SiWarga Patehan. NIK is the ID number, whereas RT and RW are subdivision of village. $\mathrm{RT}$ is the smallest subdivision in the village.

\subsection{Utilization of siwarga patehan}

The Patehan community can be divided into two groups based on the level of utilization of the Patehan SiWarga, namely the group that has used it and the group that has not. Most of the Patehan residents support the changes in the administrative service system from offline to online. Of the various features that are available, the most frequently used features are the cover letters and demography. The cover letters that is most often used in the SiWarga Patehan are the making of family card, ID card, noncriminal card, moving population, marriage, divorce, credit, domicile, building pemission, inheritance rights, and processing permit activities.

Changes in the administrative service system are seen as a complement to the offline service system so it could ease the duties of the Head of the RT/RW in providing services to the community, especially for the Head of RT/RW who have high mobility jobs such as tour guides or entrepreneurs who are not always staying at their homes. In addition, the online service system is seen as more practical, fast, effective and efficient. This is as stated by the informant as follows:

"From the aspect of service, it has become one of the right solutions. For p- ISSN 2528-1410 e- ISSN 2527-8045 | 
example, the heads of RT and RW who are not at home can still serve. "(Informant 01: The Head of LPMK)

"With SiWarga, RW can provide real time services. Because the manual process is difficult and I still have to wait for it, even though I have to work out of town, sometimes there are letters that must be done immediately but then have to be delayed for a few days." (Informant 07: The Head of RW 5)

"I'm supporting it, I happen to be not domiciled here so I rarely go home so I prefer to use SiWarga." (Informant 17: RT 21 residents)

The online administration service system (SiWarga Patehan) has been used for 1 year starting in January 2017. SiWarga Patehan users have been actively using the online service system after SiWarga was officially launched by acting Mayor of Yogyakarta. Based on SiWarga Patehan user data on
January $1^{\text {st }} 2017$ to March $6^{\text {th }} 2018$, the number of SiWarga Patehan's cover letters has reached 463 letters, of which 277 letters of introduction have been processed, 136 letters are still in the processing, and 50 letters are rejected by the RT/RW administrators and the village.

The number of requests for letters in Patehan every month is dynamic. Based on Figure 2 the number of request letters from January 2017 to March 2018 indicates that request letters in the middle of the month tend to increase compared to other months. The highest number of request letters is in July 2017, which is 37 letters. Requests for cover letters in July were dominated by applications for population documents such as KTP, and SKCK. In addition, because July is the beginning of the new school year, some communities also need a letter for school needs, such as certificate of incapacity (SKTM).

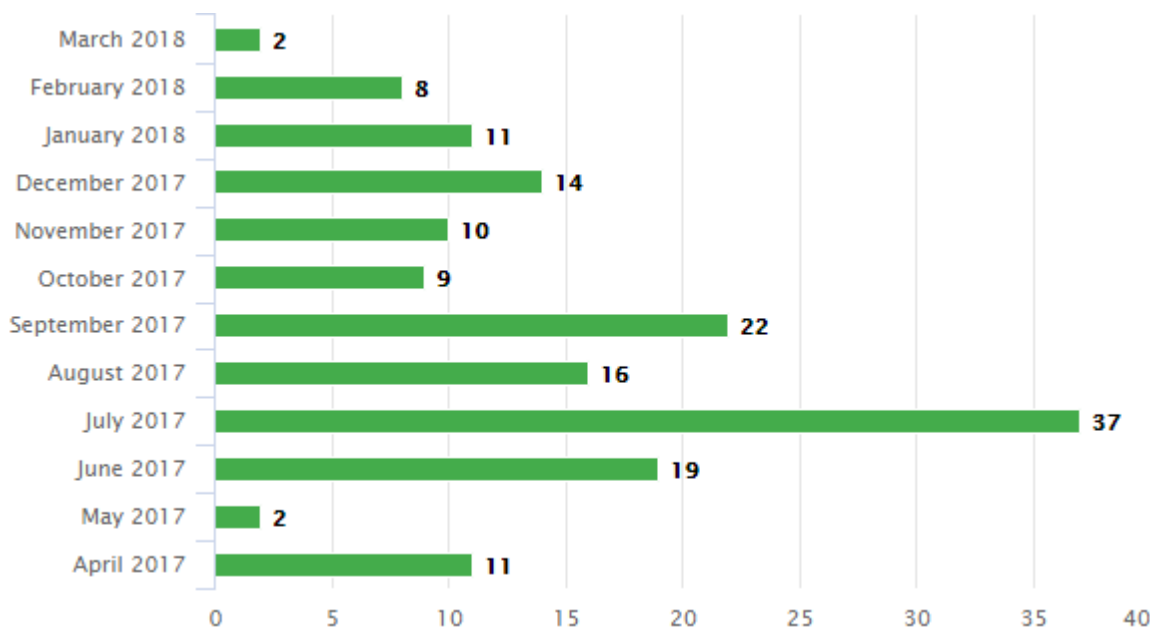

Figure 2. Frequency of SiWarga Users

The Patehan space pattern based on the level of utilization shows that the more edges of the area, the higher the level of utilization, and vice versa. The more middle the area, the lower the utilization rate. This is in line with Figure 3 which shows the affordability of | DOI: http://dx.doi.org/10.17509/ijost.v4i1.12680 I p- ISSN 2528-1410 e- ISSN 2527-8045
Patehan Village with the user of the SiWarga Patehan. At a radius of 100 meters from the Patehan, the SiWarga Patehan user is quite a few, compared to the number of users who are at a radius of 300,500 , even $700 \mathrm{~m}$. SiWarga Patehan users are mostly at a radius 
of 700 meters located in RW 1, 2, and 5. This shows that the use of SiWarga is more dominated by areas located far from the Patehan compared to areas close to the Patehan. The farther from Patehan, people tend to use SiWarga Patehan more often, especially in accessing information about Patehan.

Based on Figure 4, the level of utilization of types of administrative letters in each RW is different, however, the changes and the making of KTP and KK are still the most frequently requested types of population administration letters. In line with the level of utilization, RW 9 becomes one of the areas with the highest utilization rate for types of administrative letters relating to changes and the making of KTP. It is inversely proportional to RW 3 which rarely uses SiWarga applications so that in this RW the type of utilization of administrative letters is limited to making KIA. In addition to the administrative letter for the making of KTP or KK, some residents also often use the SiWarga Patehan to make other certificates such as income certificates, KMS, business licenses, death certificates, and other general letters. Based on SiWarga's utilization data, it can be analyzed that the high and low frequency of using SiWarga is influenced by five factors. The factors are the level of public awareness, policies of RT/RW administrators, individual ability to access the internet, level of mobility, and ignorance of the SiWarga Patehan application. As forsome constraints in the preparation and implementation of SiWarga, among others are the limited
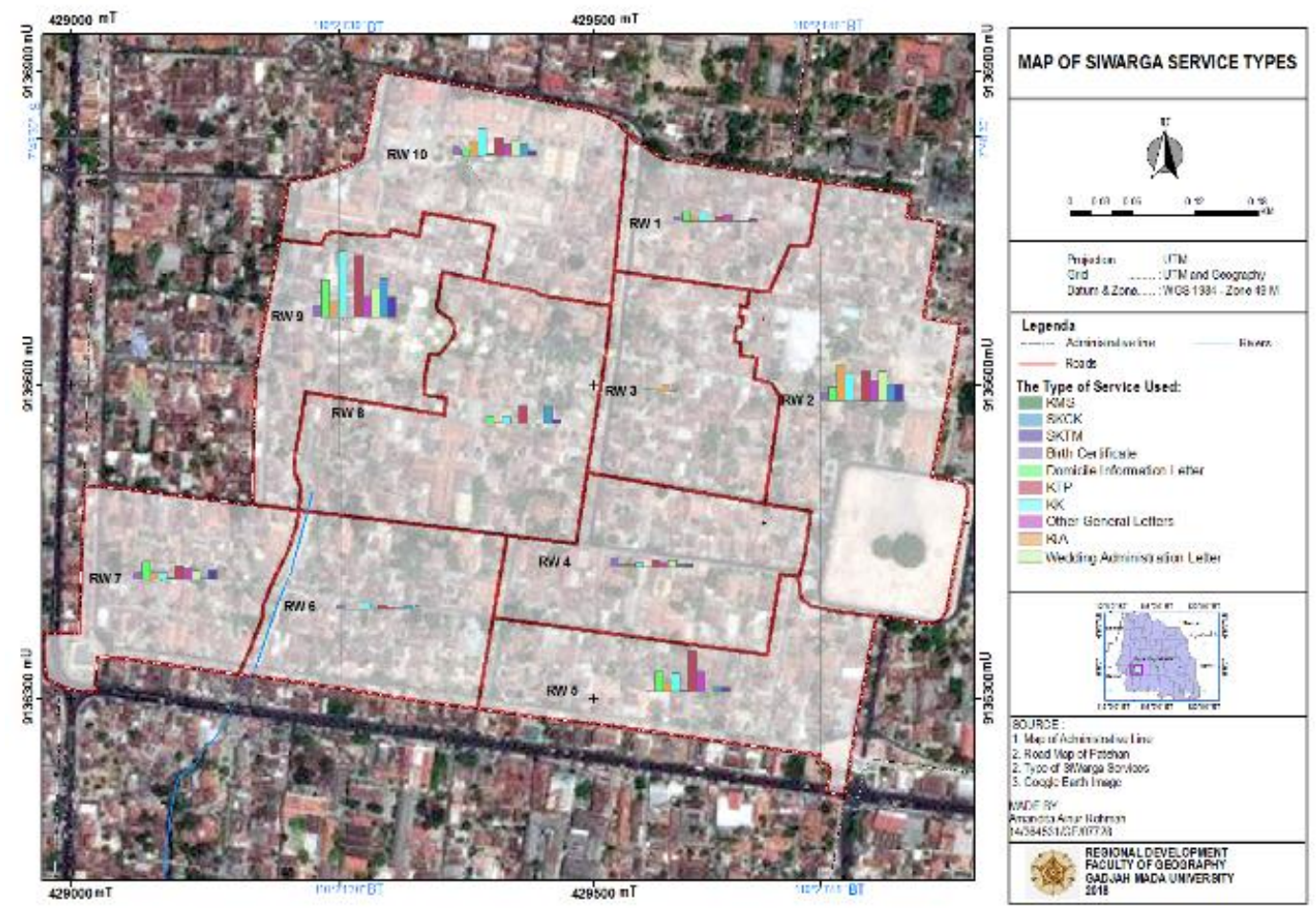

Figure 3. Map of SiWarga Service Types 


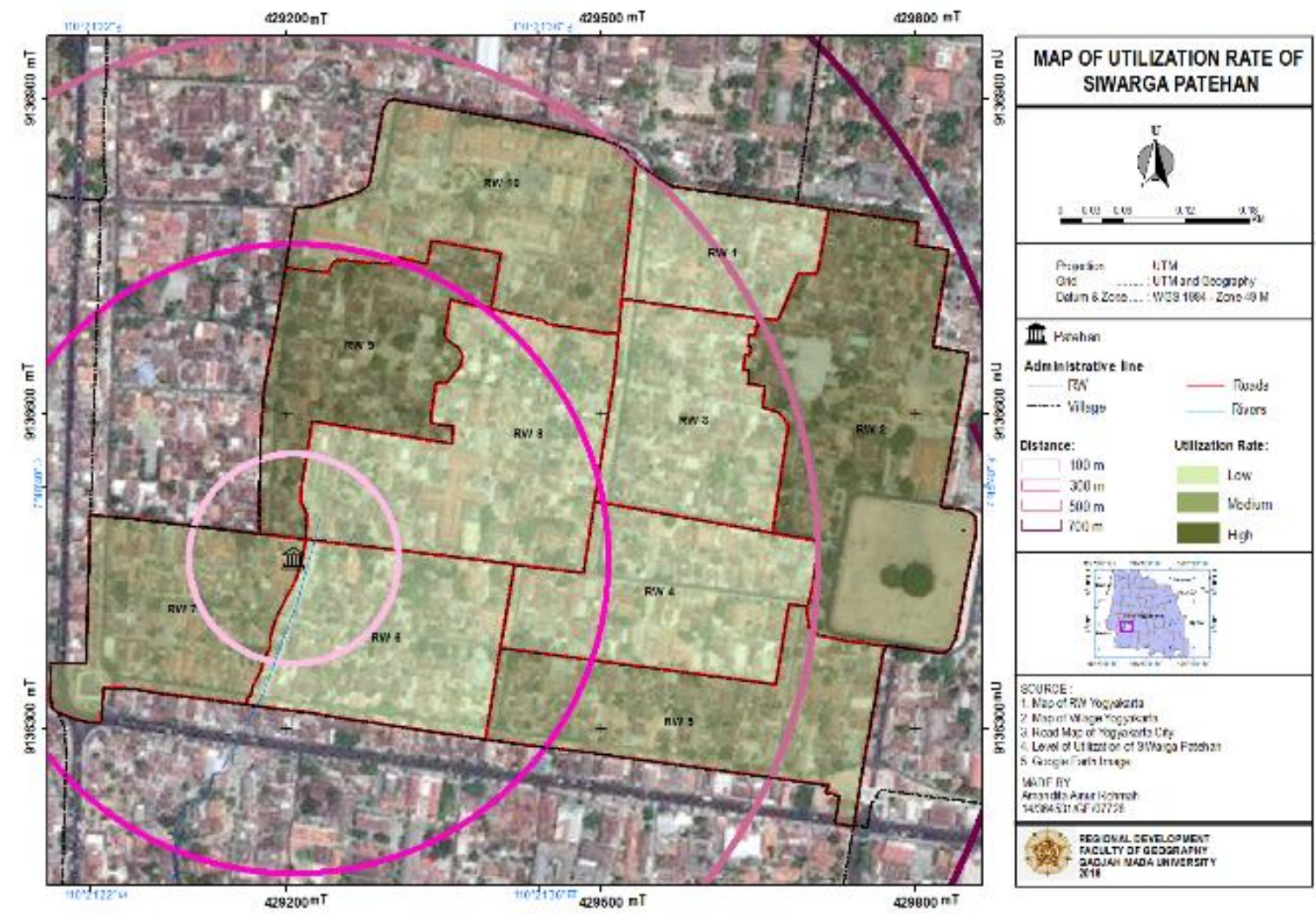

Figure 4. Map of Utilization Rate of SiWargaThe Mechanism and Flow of SiWarga

ownership of smartphone communication devices, age factors, the level of public finances, version changes, community paradigms, and cultural shock.

\subsection{Quality of siwarga patehan}

The measurement of the quality of SiWarga Patehan services is obtained from the results of community perceptions of the quality of its services. The service quality of SiWarga Patehan is identified based on Alanezi's dimensions (2010) by using seven dimensions as determinants of service quality. The Alanezi dimension measures the quality of e-government services by reformulating the five dimensions of the SERVQUAL scale (Zeithaml, 1998) and adding two new dimensions relevant to the concept of e-government. The seven dimensions used are Website Design, Reliability, Responsiveness, Security and Privacy, Personalization, Information, and Easily use.
The measurement of SiWarga Patehan's service quality was obtained from the perception of 60 respondents who were Patehan residents. Of the total number of respondents, $13 \%$ of respondents filled in the google form questionnaire. This shows that the level of community in Patehan, especially SiWarga application users has been digitally literate. In line with the level of digital literacy of the Patehan community, SiWarga Patehan service quality index shows a pretty good number with a value of 79.97 (see Table 1). The index of service quality in Patehan is categorized as Good. More than 50\% of respondents of SiWarga users stated that of the seven aspects of Alanezi peforma SiWarga Patehan were good. The best quality of service is in the dimensions of reliability that is equal to 81.46 , while the dimensions of information become dimensions with the lowest quality of service that is equal to 78.47. 
Table 1. SiWarga Service Quality Index

\begin{tabular}{clcc}
\hline No & \multicolumn{1}{c}{ Dimension } & $\begin{array}{c}\text { Dimensions of Service } \\
\text { Quality Index }\end{array}$ & Service Quality Index \\
\hline 1 & Website Design & 79.03 & \\
2 & Reliability & 81.46 & \\
3 & Responsiveness & 80.42 & \\
4 & Security & 80.00 & 79.97 \\
5 & Personalization & 79.86 & \\
6 & Information & 78.47 & \\
7 & Ease of Use & 80.56 & \\
\hline
\end{tabular}

The dimension of reliability is an aspect of the best service quality, seen from the reability and accuracy aspects of the SiWarga Patehan. All respondents consider that SiWarga Patehan basically can be reliable for the community. In addition, in terms of timeliness of service, respondents consider SiWarga to be quite on time, which means that SiWarga can be relied upon as an alternative solution for administrative matters. In contrast to the dimensions of reliability, the dimensions of Information in SiWarga Patehan have the lowest service quality index compared to other dimensions. Information dimensions are considered sufficient but still need improvement. Information on SiWarga Patehan has not updated and complete yet. In addition, the information is only dominated by information in the form of text.

\section{CONCLUSION}

Based on the results of the study, it can be concluded that; SiWarga is a digital service system for people who need effective, efficient and innovative digital service system for the community that is demonstrated by online services and does not require face to face between the community and the RT/RW administrators, as well as accessible services in an unlimited place and time. Residents of Patehan can be divided into two groups based on the level of SiWarga Patehan utilization, namely the group that have already used it and group that have not. The use is shown by the number of introductory letters for SiWarga Patehan that has reached 463 letters ( 277 have been processed, 136 are in the processing, and 50 letters have been rejected by the RT / RW). Regarding the quality of service, most of the people stated that they were good (79.97\%), while the best quality of service is in the dimensions of reliability with 81.46 points.

\section{ACKNOWLEDGEMENTS}

This project was sponsored by Department of Geography Development, Faculty of Geography, Universitas Gadjah Mada, Indonesia, as well as Grace and Company for donating materials for the research.

\section{AUTHORS' NOTE}

The author(s) declare(s) that there is no conflict of interest regarding the publication of this article. Authors confirmed that the data and the paper are free of plagiarism. 


\section{REFERENCES}

Alanezi, M. A., Kamil, A., and Basri, S. (2010). A proposed instrument dimensions for measuring e-government service quality. International Journal of u-and e-Service, Science and Technology, 3(4), 1-18.

Paramita, B., Kamilia, I., Nurhidayat, M. I., and Ocktaviyane, R. (2016). Optimization of Design and Planing VHS Building Using Chronolux. Indonesian Journal of Science and Technology, 1(2), 170-184.

Firdaus, C., Wahyudin, W., and Nugroho, E. P. (2017). Monitoring System with Two Central Facilities Protocol. Indonesian Journal of Science and Technology, 2(1), 8-25.

Gasova, K., and Stofkova, K. (2017). E-government as a quality improvement tool for citizens' services. Procedia Engineering, 192, 225-230.

Governor Regulation No. 42 of 2006 concerning Jogja Cyber Province Blueprint, DIY Provincial Government.

Haristiani, N., and Firmansyah, D. B. (2016). Android application for enhancing Japanese JLPT N5 kanji ability. Journal of Engineering Science and Technology, 12, 106-114.

Haristiani, N., and Aryadi, S. (2017). Development of android application in enhancing learning in Japanese kanji. Pertanika Journal of Science and Technology, 25, 157-164.

Mayor Regulation No. 15 of 2015 about E-Government

Mayor Regulation Number 78 of 2007 concerning E-Government

Presidential Instruction No. 3 of 2003 concerning National E-government Development Policy and Strategy

Rachmawati, R. (2014). Urban Development in The Era of Information and Communication Technology. Yogyakarta: Gadjah Mada University Press.

Rachmawati, R. (2016). Urbanization in The Era of Information and Community Technology (ICT). Rapid Urbanisation and Sustainable Development in Asia. 9, 58-67.

Rachmawati, R., Ramadhan, E. R., and Rohmah, A. A. (2018). Aplikasi Smart Province "Jogja Istimewa": Penyediaan Informasi Terintegrasi dan Pemanfaatannya. Majalah Geografi Indonesia, 32(1), 14-23.

Sosiawan, E.A. (2008). Communication and Administration Management Model of Back Office E-Government as a Public Media Service. Journal of Communication Sciences, 10, 3-10.

UNDESA. (2016). United Nations E-Government Survey 2016 E-government in Support of Sustainable Development. New York: United Nations.

Yousaf, M., Ihsan, F., and Ellahi, A. (2016). Exploring the impact of good governance on citizens' trust in Pakistan. Government Information Quarterly, 33(1), 200-209.

Parasuraman, A., Zeithaml, V. A., and Berry, L. L. (1988). Servqual: A multiple-item scale for measuring consumer perc. Journal of Retailing, 64(1), 12. 